\title{
Turbid waters and clarifying mussels: their moderation of empirical chl:nutrient relations in estuaries in Prince Edward Island, Canada
}

\author{
J. J. Meeuwig*, J. B. Rasmussen, R. H. Peters \\ Department of Biology, McGill University, 1205 ave Dr. Penfield, Montréal, Quebec H3A 1B1, Canada
}

\begin{abstract}
Coastal eutrophication has been identified as an important ecological problem in many regions. Yet simple, generalizable models, such as those available for the management of lake eutrophication, do not exist for estuaries. As a first step in the development of estuarine eutrophication models, we generated chlorophyll a:nutrient regression models for 15 estuaries in Prince Edward Island, Canada. Total phosphorus and total nitrogen account for 65 and $72 \%$ of the variance in chlorophyll (chl), respectively. However, when these models are compared to similar models for lakes, the yield of chl per unit nutrient is between 1 and 2 orders of magnitude lower in estuaries than in lakes. As herbivory and turbidity are likely contributors to this low yield, we used a mass-balance approach to model phytoplankton biomass as a function of primary production and losses due to flushing, sedimentation and herbivory. In the 6 estuaries with mussel aquaculture, 45 to $88 \%$ of the chl deficit could be accounted for by herbivory. In the remaining 9 estuaries, turbidity accounted for 35 to $75 \%$ of the chl deficit. Considering both herbivory and turbidity, the mass-balance accounted for on average $68 \%$ of the chl deficit for the 15 estuaries. We also generated an empirical model predicting the deficit as a function of herbivory and turbidity; this model accounted for $50 \%$ of the variation in the deficit. The analysis suggests that chl:nutrient relations can be generalized across fresh and estuarine aquatic systems if turbidity and herbivory are considered.
\end{abstract}

KEY WORDS: Coastal eutrophication - Regression - Phosphorus - Nitrogen · Iron · Mytilus edulis . Aquaculture

\section{INTRODUCTION}

Coastal eutrophication is recognized as an important ecological problem in many regions [e.g U.S. Atlantic coast (Bricker et al. 1995) and the Baltic (Rosenberg et al. 1990)]. Nutrient loading to coastal waters resulting in increased phytoplankton biomass has been linked to increased incidence of toxic phytoplankton blooms (Paerl 1995) and increased anoxia both locally (Cooper 1995) and on the continental shelf (Turner \& Rabalais 1994). Concern over coastal eutrophication is reflected in the U.S. Estuarine Eutrophication Survey (Bricker et al. 1995), and 2 primary journals have dedicated issues to the topic (Nixon 1990, Vollenweider et al. 1992).

Because eutrophication is defined as an aquatic system's response to nutrient loading (Edmondson 1991), identification of the key nutrient controlling coastal

\footnotetext{
-E-mail: jmeeuwig@bio1.lan.mcgill.ca
}

phytoplankton biomass is considered essential. Based on the stochiometric work of Redfield (1958), phosphorus (P) has been considered a key limiting nutrient in marine systems. Moreover, P control of phytoplankton biomass in many freshwater systems and similarities in phytoplankton physiology and nutrient requirements in both coastal and freshwater systems (Hecky \& Kilham 1988) make P control of coastal systems intuitively appealing. Nevertheless, following Ryther \& Dunstan's (1971) influential work, nitrogen (N) is generally seen as the limiting nutrient in coastal systems and has received the bulk of research interest. A review of the 1995 to 1997 biological abstracts shows that, of 596 articles on estuaries and nutrients, $52 \%$ consider only nitrogen, $32 \%$ refer to both nitrogen and phosphorus, and $16 \%$ consider only phosphorus.

Despite the preponderance of research on $\mathrm{N}$, the evidence for general $\mathrm{N}$ limitation of coastal systems is weak compared to the evidence for general P limita- 
tion of freshwater systems. In their comparative review of nutrient limitation in aquatic systems, Hecky \& Kilham (1988) argued that, although $N$ may well be the key limiting nutrient in coastal waters, the evidence is inconclusive as it is mostly derived from bioassays and observations of inorganic nutrient concentrations. Since this review, a series of mesocosm experiments on $N$ versus $P$ limitation have been conducted (e.g. Oviatt et al 1995, Tamminen 1995). However, whole system experiments such as those of Schindler (1977) that provided such convincing evidence of $P$ limitation in lakes are absent in coastal areas. Coastal and marine ecologists have also generally eschewed the comparative approach of limnologists (e.g. Dillon \& Rigler 1974), which has been instrumental in establishing the generality of $\mathrm{P}$ limitation in lakes. Although limited examples of comparative work in the coastal literature exist (cf. Nixon 1981, Monbet 1992, Boynton et al. 1996), the relative strength of patterns between phytoplankton biomass and total $N$ (TN) and total P (TP) in estuaries has not been tested.

To evaluate patterns between phytoplankton biomass and nutrients, the following hypotheses were tested: (1) estuarine phytoplankton biomass [measured as chlorophyll a (chl)] is primarily a function of bottomup nutrient control; (2) chlinutrient relations can be established using a comparative, empirical approach; (3) the relation between chl and TP is stronger than that between chl and $T N_{i}$ and (4) chl responds to total nutrient concentrations similarly in estuaries and lakes. We also examine the role of herbivory and turbidity in moderating the relation between nutrients and coastal phytoplankton biomass.

\section{METHODS}

Study location. This analysis is based on data from 15 estuaries in Prince Edward Island (PEI), Canada. PEI is a small island (575000 ha; Environment Canada 1990) located in the Gulf of the St. Lawrence River, approximately $15 \mathrm{~km}$ from the New Brunswick coast (Fig. 1). Maximum salinity surrounding PEI is approximately $29 \%$, reflecting the strong influence of the Gulf of St. Lawrence. The island is heavily bisected by rivers flowing into approximately 25 coastal embayments along a $1600 \mathrm{~km}$ coastline (Environment Canada 1990). These embayments include coastal plain estuaries (Fairbridge 1980) as well as lagoons that form behind barrier sandbars on the Island's north shore. Tides are semi-diurnal with a mean high tide of $0.9 \mathrm{~m}$ and mean low tide of $0.2 \mathrm{~m}$ on the north shore and a mean high tide of $2.4 \mathrm{~m}$ and mean low tide of $0.5 \mathrm{~m}$ on the south shore (Department of Fisheries and Oceans 1996).

Agriculture is an important economic activity on the island: approximately $35 \%$ of the land base is agricultural (MacDougall et al. 1988). The soils are generally acid, well-drained podzols (MacDougall et al. 1988). These podzols erode easily and soil loss can be as high as 40 to 45 tonnes $\mathrm{ha}^{-1} \mathrm{yr}^{-1}$ (Himmelman \& Stewart 1979). Because podzols are low in organic matter (<3\%; MacDougall et al. 1988) and because of the intensity of agricultural activity, synthetic fertilizers are heavily used 11100 to $1600 \mathrm{~kg} \mathrm{ha}^{-1}$ of 13:20:20 N:P:K fertilizer; B. Thompson, Prince Edward Island Department of Agriculture and Forestry, pers. comm.). Nitrogen leaches into ground water through podzols

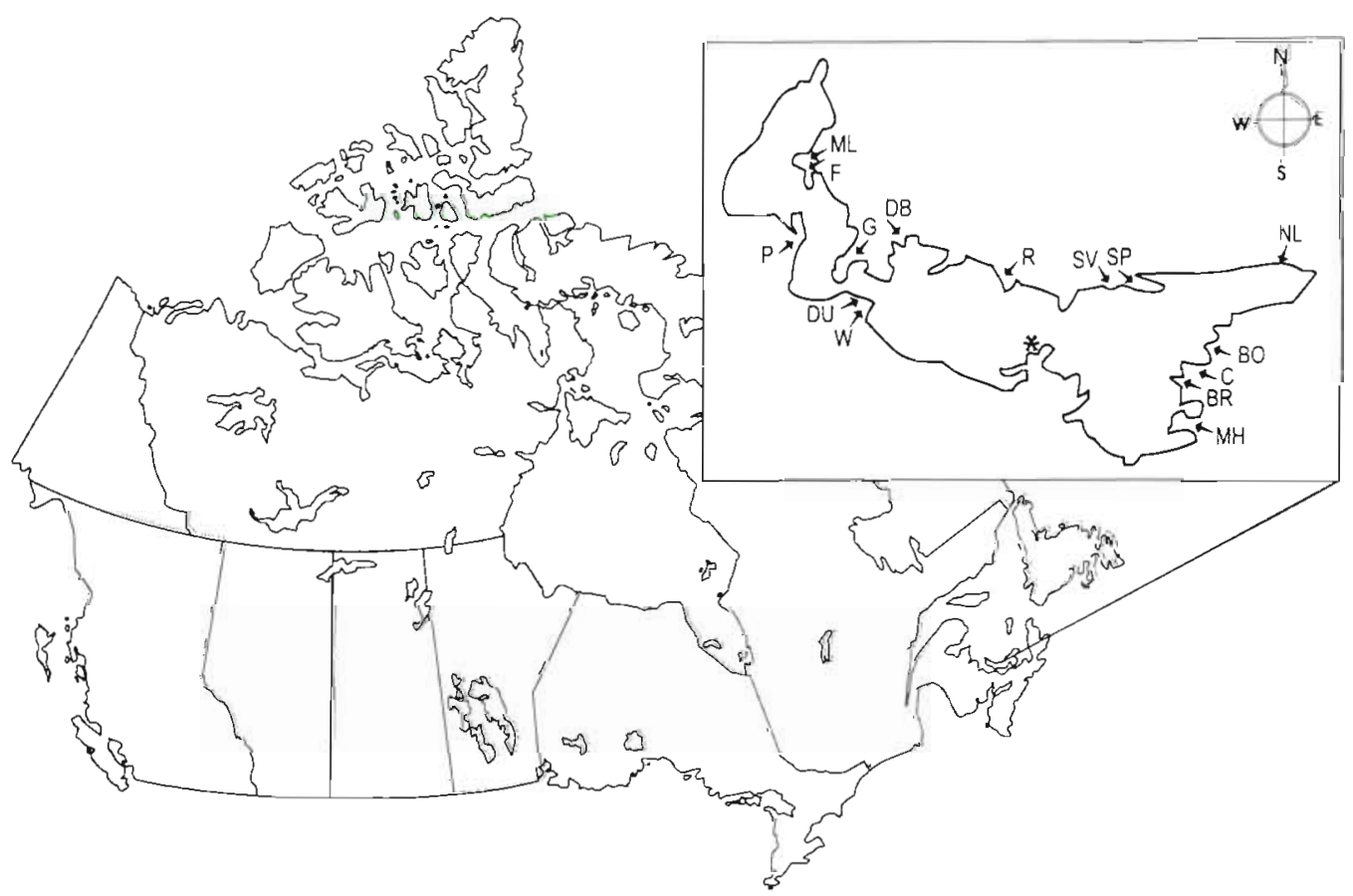

Fig. 1 Location of Prince Edward Island, Canada, and the 15 study estuarles; asterix indicates the provincial capital, Charlottetown. BO: Boughton; BR: Bruderell, C: Cardigan; DB: Darnley Basin; DU: Dunk, F: Foxley; G: Grand; $M H$ : Murray River; ML; Mill River; NL: North Lake; P: Percival; R: Rustico; SP: St. Peters; SV Savage Harbour; W. Wilmot 
Table 1 Data for 15 estuaries from Prince Edward Island used in this analysis. Mussel welght is in grams dry weight

\begin{tabular}{|c|c|c|c|c|c|c|c|c|c|c|c|}
\hline Site & $\begin{array}{c}\text { Chl } \\
\left(\mathrm{mg} \mathrm{m}^{3}\right)\end{array}$ & $\begin{array}{c}\text { Total } \\
\text { phosph. } \\
\left(\mathrm{mg} \mathrm{m}^{-3} \text { ) }\right.\end{array}$ & $\begin{array}{c}\text { Total } \\
\text { nitrogen } \\
\left(\mathrm{mg} \mathrm{m}^{-3}\right)\end{array}$ & $\begin{array}{l}\text { Secchl } \\
\text { depth } \\
(\mathrm{m})\end{array}$ & $\begin{array}{c}\text { Mean } \\
\text { depth } \\
(\mathrm{m})\end{array}$ & $\begin{array}{l}\text { Volume } \\
\left(\times 10^{6} \mathrm{~m}^{3}\right)\end{array}$ & $\begin{array}{l}\text { Residence } \\
\text { time } \\
\text { (d) }\end{array}$ & $\begin{array}{l}\text { Salinity } \\
\qquad\left(w_{0}\right)\end{array}$ & $\begin{array}{c}\text { Watershed } \\
\text { area } \\
\left(\mathrm{km}^{2}\right)\end{array}$ & $\begin{array}{c}\text { Agri- } \\
\text { culture } \\
\left(\mathrm{km}^{2}\right)\end{array}$ & $\begin{array}{c}\text { Mussel } \\
\text { weight } \\
\left(\times 10^{7} \mathrm{~g} \mathrm{dw}\right)\end{array}$ \\
\hline Boughton & 1.398 & 57.9 & 209 & 3.5 & 18.0 & 140 & 332 & 21.2 & 39.5 & 10.3 & 7.29 \\
\hline Brudenell & 1.952 & 58.8 & 229 & 3.3 & 14.5 & 101 & 44 & 22.2 & 187.0 & 66.5 & 2.03 \\
\hline Cardigan & 1.548 & 550 & 241 & 4.1 & 17.6 & 225 & 255 & 21.0 & 80.5 & 21.4 & 675 \\
\hline Darnley Basin & 1.369 & 45.8 & 213 & 2.4 & 8.7 & 33 & 129 & 20.5 & 25.1 & 20.4 & 0 \\
\hline Dunk & 5.915 & 85.1 & 481 & 1.2 & 3.1 & 13 & 9 & 16.4 & 202.4 & 140.4 & 0 \\
\hline Foxley & 2.029 & 76.0 & 264 & 2.1 & 7.4 & 39 & 135 & 18.3 & 37.5 & 3.0 & 0 \\
\hline Grand & 1.453 & 45.8 & 241 & 2.5 & 11.2 & 264 & 245 & 20.1 & 110.0 & 44.0 & 0 \\
\hline Murray River & 1.301 & 60.2 & 218 & 3.7 & 10.0 & 351 & 356 & 20.4 & 101.3 & 18.0 & 9.63 \\
\hline Mill River & 3.846 & 89.6 & 367 & 2.0 & 7.7 & 30 & 33 & 18.4 & 117.9 & 56.3 & 0 \\
\hline North Lake & 4.653 & 85.2 & 312 & 1.6 & 2.3 & 2.5 & 6 & 19.9 & 45.6 & 5.1 & 0 \\
\hline Percival & 1.097 & 61.6 & 266 & 1.3 & 5.0 & 60 & 166 & 17.9 & 46.4 & 2.4 & 0 \\
\hline Rustico & 1.988 & 55.4 & 274 & 2.3 & 7.1 & 53 & 83 & 19.8 & 67.4 & 46.6 & 2.70 \\
\hline St. Peters & 1.713 & 68.6 & 298 & 2.9 & 10.3 & 140 & 61 & 18.4 & 292.9 & 75.9 & 6.39 \\
\hline Savage Harb. & 1.571 & 60.1 & 277 & 1.6 & 5.8 & 19 & 74 & 20.5 & 25.6 & 4.7 & 0 \\
\hline Wilmot & 3.475 & 94.8 & 416 & 1.1 & 2.2 & 2.3 & 3 & 19.2 & 206.6 & 65.1 & 0 \\
\hline Mean & 2.354 & 66.7 & 287 & 2.4 & 8.7 & 98 & 129 & 19.6 & 105.7 & 38.7 & 5.80 \\
\hline SD & 1.437 & 15.7 & 79 & 1.0 & 5.0 & 106 & 118 & 1.5 & 81.3 & 38.1 & 2.90 \\
\hline Min. & 1.097 & 45.8 & 209 & 1.1 & 2.2 & 2.3 & 3 & 16.4 & 25.1 & 2.4 & 2.03 \\
\hline Max. & 5.915 & 94.8 & 481 & 4.1 & 18.0 & 351 & 356 & 22.2 & 292.9 & 140.4 & 9.63 \\
\hline
\end{tabular}

and it is thus transported to estuaries; phosphorus is transported to surface waters by being adsorbed to particles of the easily eroded podzols.

Data set and analyses. A data set was compiled for 1.5 estuaries in PEI (Fig. 1) that included water chemistry, shellfish biomass, coastal morphometry, and land-use variables (Table 1). The estuaries were chosen to include a range of size, land-use characteristics and both the presence and absence of mussel aquaculture.

Water chemistry: The 15 estuaries were sampled from May to August, 1996. All estuaries larger than $4 \mathrm{~km}^{2}$ were sampled at 5 stations along a land-sea salinity gradient; the remaining 4 estuaries (Darnley Basin, North Lake, Savage Harbour and Wilmot; Table 1) were sampled at 3 stations. At each station, the location, time of day, maximum depth $\left(Z_{\max }\right)$ and Secchi depth (SD) were recorded. Salinity and temperature were measured $0.5 \mathrm{~m}$ below the surface and 0.5 $m$ above the bottom. At stations where the maximum depth was less than $1 \mathrm{~m}$, single salinity and temperature readings were taken at $0.5 \mathrm{~m}$ depth. Integrated water samples were taken at each station from the surface to $5 \mathrm{~m}$; if the depth was less than $5 \mathrm{~m}$, integrated samples were taken from the surface to $0.5 \mathrm{~m}$ above the bottom. Each estuary was sampled 6 times during the sampling season at approximately $2 \mathrm{wk}$ intervals, generating 18 ( 3 stations per estuary) or 30 (5 stations per estuary) observations per estuary.

Triplicate samples were analyzed for chl, TP and TN For chl, 0.5 l water was filtered onto Gelman A/E, which were then frozen. Within 6 mo of sampling, the filters were extracted in 90\% ethanol and chl was determined spectrophotometrically following Bergmann \& Peters (1980). TP was also determined spectrophotometrically following the persulfate digestion method of Menzel \& Corwin (1965). The methad was modified in that, after digestion, a $2 \mathrm{ml}$ subsample was taken from each replicate. These subsamples were then frozen to be read on an Alpkem autoanalyzer (Alpkem 1992) within 6 mo of sampling. TN, like TP, was determined on the autoanalyzer using $2 \mathrm{ml}$ subsamples from samples that were digested following Solórzano \& Sharp (1980).

Shellfish biomass: The estimated production (total weight in $\mathrm{kg} \mathrm{yr}^{-1}$ ) for the 6 estuaries in which blue mussels Mytilus edulis are farmed was provided by the PEI Department of Agriculture, Fisheries and Forestry (unpubl. data; Table 1). Mussel spat are placed in the grow out bags when approximately 3 mo old and 20 to $30 \mathrm{~mm}$ long; they are harvested in the 50 to $60 \mathrm{~mm}$ size range. A total of $13 \mathrm{~km}^{2}$ are under production in PEI (Table 1; Department of Fisheries and Oceans, Halifax, Canada, unpubl. data).

Mussel filtration rates are frequently reported as clearance rates $\left(\mathrm{l} \mathrm{h}^{-1}\right)$ as a function of dry weight (Table 2). We converted all clearance rates to specific filtration rates $\left(f_{m} ; \mathrm{m}^{3} \mathrm{~d}^{-1} \mathrm{~g}^{-1}\right.$ dry wt) using conversion factors calculated from length, total weight, and dry weight measurements for 50 PEI mussels (Table 2).

Coastal morphometry and land use: Coastal morphometry was determined from bathymetric charts published by the Canadian Hydrographic Service 
Table 2. Equations used for the calculation of specific mussel filtration rates $\left(f_{\mathrm{m}} ; \mathrm{m}^{3} \mathrm{~g}^{-1} \mathrm{dry}\right.$ wt $\left.\mathrm{d}^{-1}\right)$, where $C R=c l e a r a n c e$ rate in $\mathrm{lh}^{-1}$, and $\mathrm{gl}_{\mathrm{D}}=$ grams dry weight

\begin{tabular}{|c|c|c|c|}
\hline$f_{\mathrm{m}}$ & Equation & Range of dry art (g) & Source \\
\hline $0.029-0.043$ & $0.84-1.251 \mathrm{~h}^{-1}$ for $55 \mathrm{~mm}$ animal $\mathrm{l}^{\mathrm{d}}$ & 0.7 & Jørgensen (1966) \\
\hline 0.063 & $\mathrm{CR}=2.410 \mathrm{~g}_{\mathrm{D}} 0.74$ & $0.003-1.186$ & Winter (1973) \\
\hline 0.108 & $\mathrm{CR}=3.90 \mathrm{~g}^{\circ}{ }^{0.6}$ & $0.008-1.0$ & Vahl (1973) \\
\hline 0.121 & $\mathrm{CR}=3.846 \mathrm{~g}_{\mathrm{D}}^{0.25}$ & $0.5-4.0$ & Walne (1972) \\
\hline 0.202 & $\mathrm{CR}=7.45 \mathrm{~g}_{0}^{066}$ & $0.011-1.361$ & Møhlenberg \& Riısgård (1979) \\
\hline 0.427 & Average of data & $0.07-0.39$ & Famme et al. (1986) \\
\hline
\end{tabular}

(1980). Land use information was provided by the PEI Department of Agriculture. For each watershed, land use is divided into area under forest, area under potato crops and 'other', which includes area under hay, grain, and vegetables.

Statistical analyses: Chl:nutrient relations were developed using least squares regression techniques (Zar 1984, SAS Institute 1985). Mean values for chl, TP and TN were calculated by averaging the values for the stations for each of the 6 sampling rounds. Means and standard deviations were then calculated from these 6 values to yield growing-season averages. The growing-season averages were log-transformed to stabilize variance.

\section{RESULTS}

\section{Chl:nutrient relations}

The chl:TP and chl:TN relations are both highly significant, accounting for 65 and $72 \%$ of the variation in chl respectively (Fig. 2). The estuarine chl:nutrient relations were then compared to lake chl:nutrient relations. For the TP comparison, we chose the Dillon \& Rigler (1974) equation because of the strength of its correlation and the OECD (1982) equation as it was developed for lakes from a wide geographical range (Table 3). For the TN comparison, we used the only 2 lake chl:TN models we could find: Sakamoto (1966) and Prairie et al. (1989) (Table 3).

When the PEI chl:nutrient relations are compared to the lake relations, we see that, although the slopes are similar, the intercepts of the estuarine models are approximately 1 to 2 orders of magnitude lower than those of the lake models (Table 3). Estuarine phytoplankton yield (chl:TP and chl:TN) is much lower in PEI estuaries than in lakes. Assuming that estuarine phytoplankton can respond to nutrients similarly to lake phytoplankton, we calculated a potential chl estimate for each estuary using the observed TP values in the Dillon \& Rigler equation (Fig. 3). The difference between these potential chl values and the observed chl values can be considered to be a phytoplankton deficit'. As herbivory and turbidity are 2 possible contributors to this low yield, we then used a mass-balance approach to estimate how much of the phytoplankton deficit could be accounted for by these 2 factors.
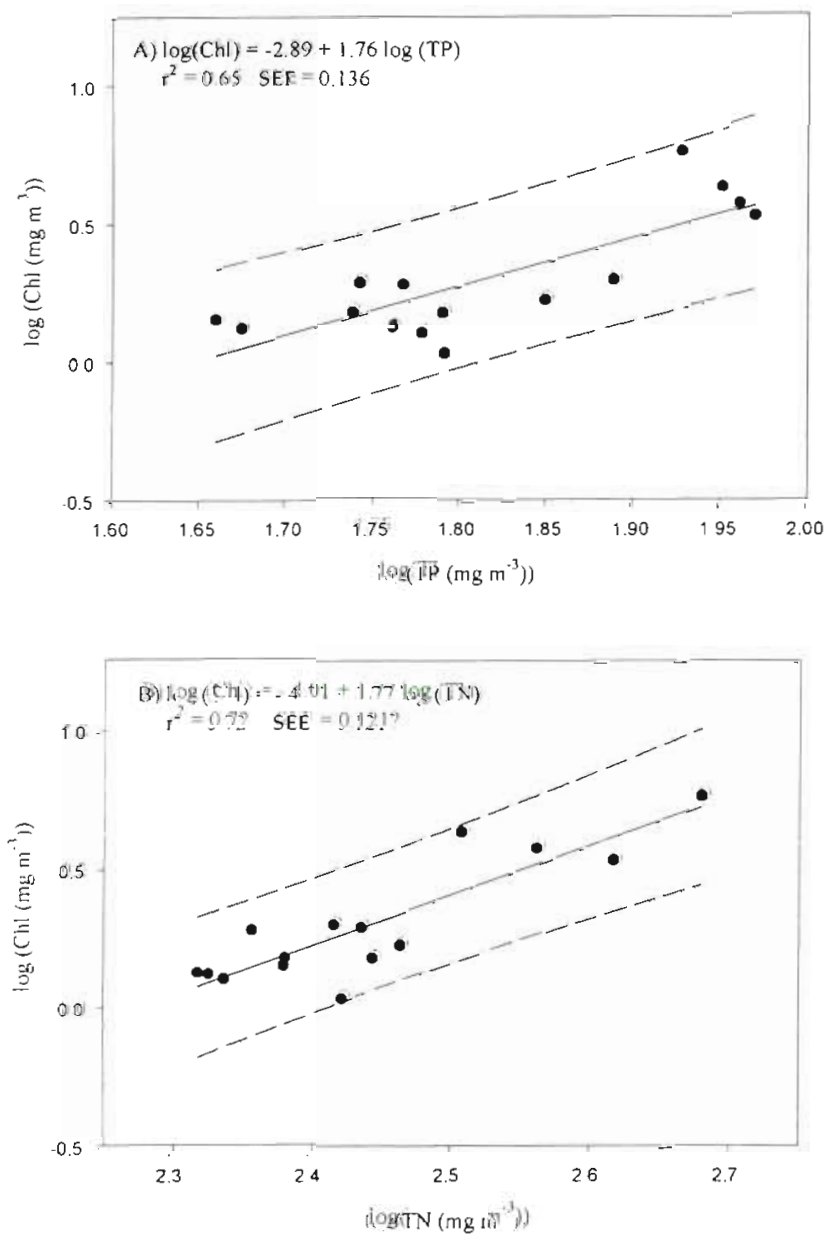

Fig. 2. Chl:TP and chl:TN relations for the 15 PEI estuaries SEE: model standard error of the estimate 
Table 3. A comparison of lake chl:nutrient relations from other studies for the 15 PEI estuaries. SEE: model standard error of the estimate. Nr.: not recorded

\begin{tabular}{|c|c|c|c|c|c|c|}
\hline Model & Slope & Intercept & $\Omega$ & $\mathrm{r}^{2}$ & SEE & Source \\
\hline $\log$ chl: $\log T P$ & 1.449 & -1.136 & 77 & 0.96 & 0.214 & Dillon \& Rigler (1974) \\
\hline Log chl: $\log T P$ & 0.96 & -0.553 & 77 & 0.88 & 0.251 & $\mathrm{OECD}(1982)$ \\
\hline Log chl $: \log T P$ & 1.76 & -2.890 & 15 & 0.65 & 0.136 & This study \\
\hline $\log c h l: \log T N$ & 1.445 & -3.131 & 133 & 0.69 & $\mathrm{nr}$ & Prairie et al. (1989) \\
\hline $\log c h l: \log T N$ & 1.40 & -2.5 & 21 & $\mathrm{nr}$ & $\mathrm{nr}$ & Sakamoto (1966) \\
\hline $\log c h l: \log T N$ & 1.78 & -4.06 & 15 & 0.72 & 0.121 & This study \\
\hline
\end{tabular}

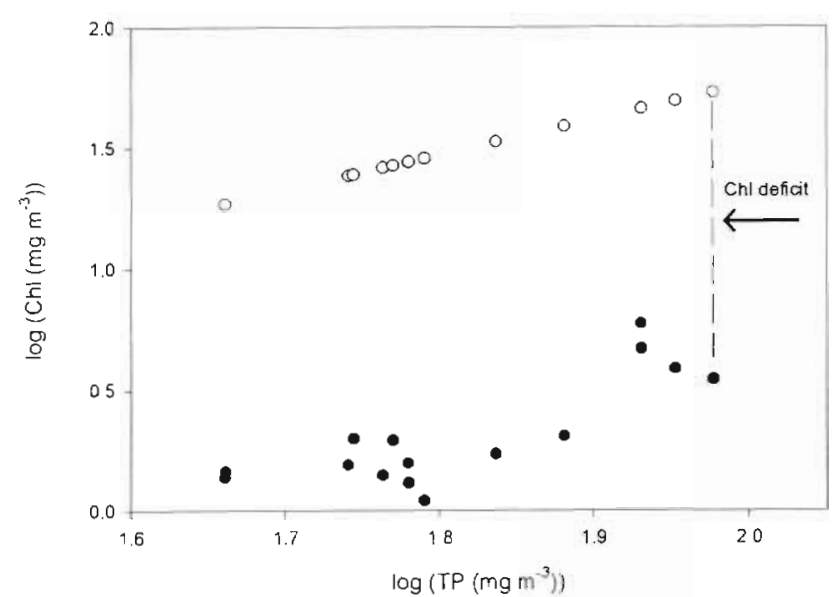

Fig. 3. Chl:TP relations calculated from the Dillon \& Rigler $(1974$ ) equation (O) and observed for the 15 PEI estuaries $(\bullet)$, demonstrating chl deficit

\section{Mass-balancing phytoplankton biomass}

The equation used to model phytoplankton growth is:

$$
\mathrm{d} B / \mathrm{d} t=\mathrm{PP}-B \cdot k_{\mathrm{L}}
$$

where $B$ is phytoplankton biomass $\left(\mathrm{mg} \mathrm{C} \mathrm{m}^{-3}\right), \mathrm{PP}$ is primary production ( $\mathrm{mg} \mathrm{C} \mathrm{m} \mathrm{C}^{-3} \mathrm{~d}^{-1}$ ) and $k_{\mathrm{L}}$ is the specific loss rate $\left(\mathrm{d}^{-1}\right)$. At steady state, $\mathrm{d} B / \mathrm{d} t$ is zero and Eq. (1) can be rewritten as:

$$
\mathrm{PP}=B \cdot k_{\mathrm{L}}
$$

To determine whether we could assume that phytoplankton biomass is at steady state, we plotted biomass as a function of time over the 6 sampling rounds for each estuary and then looked for trends in the data. In almost all the estuaries, chl fluctuated without trend around the mean (Fig. 4). We thus assumed that biomass is at steady state and that we could calculate a steady-state mass balance for phytoplankton.

In our phytoplankton mass balance, the 2 main losses in all 15 estuaries are losses via flushing and sedimentation. Thus Eq. (2) can be rewritten as:

$$
B=\mathrm{PP} \cdot\left(k_{\mathrm{f}}+k_{\mathrm{s}}\right)^{-1}
$$

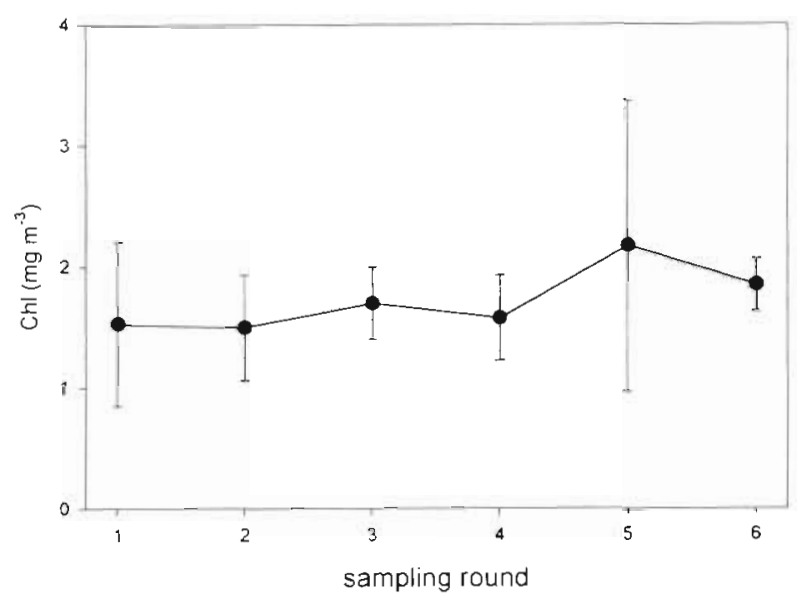

Flg. 4. Variation in chl over time for Boughton Estuary

where $k_{1}$ and $k_{\mathrm{s}}$ are the loss coefficients $\left(\mathrm{d}^{-1}\right)$ for flushing and sedimentation. The loss coefficient due to flushing, $k_{\mathrm{f}}$, is calculated using the salt-water fraction method (Bowden 1980):

$$
k_{\mathrm{f}}=Q \cdot V^{-1} \cdot\left[\left(S_{\mathrm{s}}-S_{\mathrm{m}}\right) \cdot S_{\mathrm{s}}^{-1}\right]^{-1}
$$

where $Q$ is the freshwater load $\left(\mathrm{m}^{3} \mathrm{~d}^{-1}\right), V$ is the estuary volume $\left(\mathrm{m}^{3}\right), S_{\mathrm{m}}$ is the mean salinity in the estuary $(\%)$ and $S_{\mathrm{s}}$ is the salinity $(\%)$ of open water around the island. For each estuary, the freshwater load was calculated as the product of the average daily rainfall during the period sampled (B. Raymond, Prince Edward Island Department of Fisheries and Environment, pers. comm.) and the area of the watershed. The loss coefficient due to sedimentation, $k_{\mathrm{s}}$, was calculated from the specific settling rate $\left(0.1 \mathrm{~m} \mathrm{~d}^{-1}\right.$; O'Connor 1981) divided by the mean depth of the estuary.

To estimate PP in the estuaries, we collected data for 5 estuaries along the U.S. east coast for PP (Boynton et al. 1982) and chl and TP (United States Environmental Protection Agency (US EPA) unpubl. data, retrieved from STORET (Central Data Repository)]. We calculated the means and coefficients of variation for these 3 variables: while chl varied 6 -fold, PP varied by a factor of 2 (Table 4). This is consistent with results from Oviatt et al. (1986) demonstrating that experimental 
nutrient additions resulting in a 32 -fold increase in nutrients produced only a 3.5fold increase in PP. Given the small range of chl in the PEI estuaries, it is unlikely that $\mathrm{PP}$ varies greatly across the systems. We chose a value of $300 \mathrm{~g} \mathrm{C} \mathrm{m}^{-2} \mathrm{yr}^{-1}$ as this approximates the average value of the estuaries represented (Table 4). It also corresponds to mesotrophic status (Nixon 1995), which is consistent with our TP values.

To test whether the mass-balance calculation provides a reasonable estimate of the biomass, $B$, observed in the estuary, we calculated $B$ for all the estuaries, including only sedimentation and flushing as losses. These massbalance estimates of $B\left(B_{\mathrm{MB}}\right)$ should be comparable to the $B$ estimates from the Dillon \& Rigler (1974) equation $\left(B_{\mathrm{DR}}\right.$ we converted chl to $C$ using a $C$ : chl ratio of 50 ; Nixon et al. 1986). We plotted the Dillon \& Rigler equation and its $95 \%$ confidence bands for a predicted value (Zar 1984). The values of $B_{\mathrm{MB}}$ all fall within the prediction bands, suggesting that the values of $B_{\mathrm{MB}}$ are no less precise than the $B_{\mathrm{DR}}$ estimates (Fig. 5). We thus felt that the phytoplankton mass balance and the chosen parameters adequately estimate $B$ for these estuaries

\section{Herbivory and mass balance}

To estimate how much of the phytoplankton deficit was attributable to mussel herbivory, the impact of mussel aquaculture on phytoplankton biomass was estimated for the 6 estuaries with extensive mussel

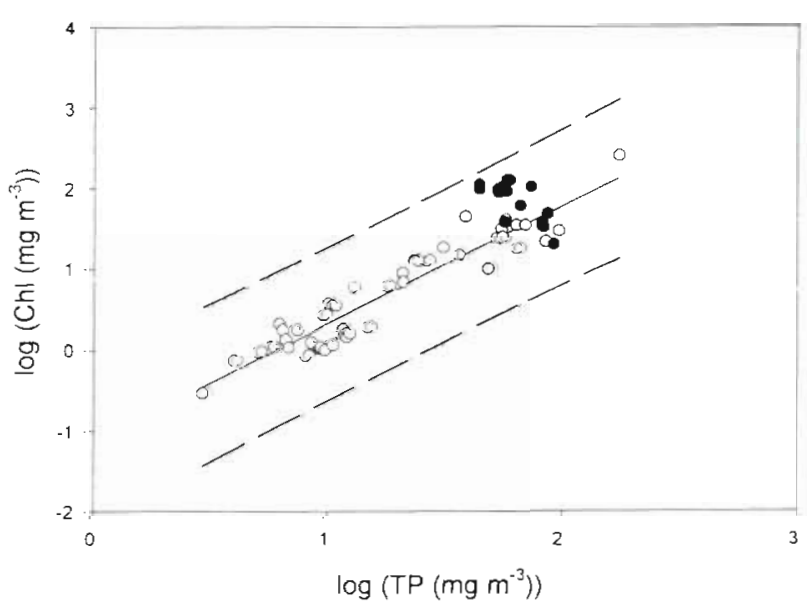

Fig. 5. A comparison of chl estimates from the Dillon \& Rigler (1974) equation (solid line) and the mass-balance estimate $(\bullet)$ demonstrating that the mass-balance estimates fall within the $95 \%$ confidence bands for predicted values (dashed lines; $\mathrm{Zar}$ 1984). (0) Original data used to fit the model farms (Table 1). The loss coefficient due to herbivory, $k_{\mathrm{h}}$, was added to the loss term in Eq. (4). It is calculated as the fraction of the estuary filtered each day by the mussels:

$$
k_{\mathrm{h}}=V_{\mathrm{F}} \cdot V^{1}
$$

where $V_{\mathrm{F}}$ is the volume filtered by the mussels per day and is equal to the product of the mussel biomass $(\mathrm{g}$ dry $w$ ) and the specific filtration rate, $f_{m}$ (Table 2). Filtration rates reported in the literature vary over an order of magnitude $\left(0.03\right.$ to $0.4 \mathrm{~m}^{3} \mathrm{~d}^{-1} \mathrm{~g}^{-1}$ dry wt), depending on the size of the mussels used, the temperature and the experimental design. We chose a value in the middle of the range of $0.108 \mathrm{~m}^{3} \mathrm{~d}^{-1} \mathrm{~g}^{-1}$ dry wt (Vahl 1973).

To determine the phytoplankton deficit attributable to mussel herbivory, we recalculated $B$ including the herbivory loss coefficient, $k_{h}$, in the mass balance. The difference between the phytoplankton biomass under herbivory, $B_{11}$, and that calculated in the absence of herbivory $\left(B_{M B}\right)$ is the phytoplankton deficit attributable to herbivory. Herbivory accounts for between 45 and $88 \%$ of the phytoplankton deficit (Table 5).

Table 5. Phytoplankton biomass deficit attributable to mussels: observed $B\left(B_{0} ; \mathrm{mg} C \mathrm{~m}^{-3}\right)$, biomass expected from the mass halance ( $B_{\mathrm{MB}}$ : $\mathrm{mg} \mathrm{C} \mathrm{m}^{-3}$ ) calculated from Eq. (3), where the loss terms are flushing $\left(k_{\mathrm{f}}\right)$ and sedimentation $\left(k_{\mathrm{s}}\right)$, biomass expected in the presence of mussels $\left(B_{H} ; \mathrm{mg} \mathrm{C} \mathrm{m}^{-3}\right)$, where herbivory $\left(k_{\mathrm{h}}\right)$ is included in the loss term of Eq. (4), and percent reduction in the phytoplankton deficit $\left[100 \times\left(B_{\mathrm{MB}}-B_{\mathrm{H}}\right) /\left(B_{\mathrm{MB}}-B_{0}\right)\right]$

\begin{tabular}{|lrrrr|}
\hline Site & $B_{0}$ & $B_{\mathrm{MB}}$ & \multicolumn{1}{c}{$B_{\mathrm{H}}$} & $\%$ reduction \\
\hline Boughton & 70 & 5328 & 704 & 88 \\
Brudenell & 98 & 1920 & 1105 & 45 \\
Cardigan & 77 & 4865 & 111 & 78 \\
Murray River & 65 & 6417 & 1936 & 71 \\
Rustico & 99 & 1424 & 1424 & 69 \\
St. Peters & 86 & 1057 & 1057 & 67 \\
\hline
\end{tabular}




\section{Turbidity}

The estimates of PP used to calculate $B_{\mathrm{MB}}$ and $B_{\mathrm{H}}$ above were volumetric and assume that PP occurs throughout the water column. Such an assumption overestimates PP, and turbidity will further decrease the depth to which PP occurs

Secchi depth can be used to estimate the depth of the euphotic zone $\left(Z_{\mathrm{E}}\right.$; Cole 1994), and convention frequently uses a $Z_{E}:$ Secchi depth ratio of 2 (Dillon \& Rigler 1974). However, turbidity and colour can reduce PAR (photosynthetically active radiation) by 66 to $99 \%$ within a meter of water (James \& Birge 1938 in Wetzel 1982). Thus, for turbid estuaries where Secchi depth was less than $2 \mathrm{~m}$ (Dunk, North Lake, Percival and Wilmot), we used a ratio of $Z_{E}$ : Secchi depth of 1 ; for the remaining estuaries which were less turbid we used the conventional ratio of 2 . The mass-balance equation thus becomes:

$$
B=\mathrm{PP}_{\mathrm{E}} \cdot\left(k_{\mathrm{f}}+k_{\mathrm{s}}+k_{\mathrm{h}}\right)^{-1}
$$

where $P P_{E}$ is the amount of $P P$ occurring in the euphotic zone:

$$
P P_{E}=P P \cdot\left(Z_{E} \cdot Z_{M}{ }^{-1}\right)
$$

where $Z_{M}$ is the mean depth of the estuary. Recalculating $B$ to include losses due to herbivory and the effect of turbidity, $B_{\mathrm{T}}$, we find that turbidity accounts for 8 to $35 \%$ of the phytoplankton deficit in the estuaries with mussels and 35 to $75 \%$ of the deficit in the other estuaries (Table 6).

Table 6 . Phytoplankton biomass deficit attributable to turbidity: observed $B\left(B_{0} ; \mathrm{mg} \mathrm{C} \mathrm{m} \mathrm{m}^{-3}\right)$, biomass expected from the mass balance ( $B_{\mathrm{MB} ;} \mathrm{mg} C \mathrm{~m}^{-3}$ ), biomass expected given reduction in primary production as a function of turbidity $\left(B_{T i}\right.$ $\left.\mathrm{mg} \mathrm{C} \mathrm{m}^{-3}\right)$, and percent reduction in the phytoplankton deficit [for estuaries with mussels $=100 \times\left(B_{H}-B_{\mathrm{T}}\right) /\left(B_{\mathrm{MB}}-B_{\mathrm{O}}\right)$; for estuaries without mussels $\left.=100 \times\left(B_{\mathrm{MB}}-B_{\mathrm{T}}\right) /\left(B_{\mathrm{MB}}-B_{0}\right)\right]$

\begin{tabular}{|lrrrr|}
\hline Site & $B_{\mathrm{n}}$ & $B_{\mathrm{MB}}$ & \multicolumn{1}{c|}{$B_{\mathrm{T}}$} & $\%$ reduction \\
\hline Boughton & 70 & 5328 & 274 & 8 \\
Brudenell & 98 & 1920 & 503 & 33 \\
Cardigan & 77 & 4865 & 518 & 12 \\
Darnley Basin & 69 & 4913 & 2710 & 45 \\
Dunk & 296 & 1914 & 741 & 72 \\
Foxley & 102 & 5316 & 3017 & 44 \\
Grand & 73 & 5638 & 2517 & 56 \\
Mill River & 192 & 2446 & 1270 & 52 \\
Murray River & 65 & 6417 & 1432 & 8 \\
North Lake & 233 & 1716 & 1193 & 35 \\
Percival & 55 & 6314 & 1642 & 74 \\
Rustico & 99 & 4423 & 922 & 11 \\
St. Peters & 86 & 3042 & 595 & 15 \\
Savage Harbour & 79 & 4606 & 2541 & 45 \\
Wilmot & 174 & 1020 & 510 & 60 \\
& & & & \\
\hline
\end{tabular}

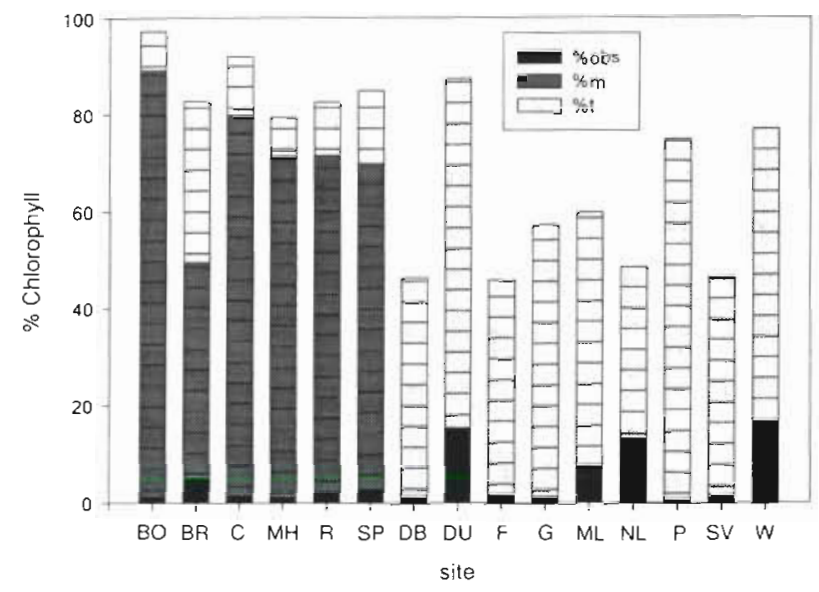

Fig. 6. Proportion of phytoplankton deficit accounted for by herbivory $(\% \mathrm{~m})$ and turbidity ( $\%$ t). $\%$ obs: proportion observed

\section{Combined effects of herbivory and turbidity in explaining the phytoplankton deficit}

The combined effects of herbivory and turbidity account for between 35 and $96 \%$ of the phytoplankton deficit (Fig 6). The average remaining phytoplankton deficit is $32 \%$. The mass balance is most effective in accounting for the phytoplankton deficit in estuaries with mussel aquaculture ( 78 to $96 \%$ of the deficit). In the remaining estuaries, the mass balance accounts for 35 to $75 \%$ of the phytoplankton deficit and on average $46 \%$ of the deficit remains. The highest remaining deficit $(65 \%)$ is in North Lake, a very small, shallow estuary that is remarkably clear for its depth, thus the mass balance had little effect.

\section{An empirical alternative to the mass balance}

We have argued that the chl deficit is a function of the loss rates (flushing, sedimentation and herbivory) and decreased primary productivity due to turbidity. Thus, it should be possible to predict the deficit empirically as a function of these loss rates and turbidity. We calculated the deficit both arithmetically:

$$
\operatorname{Def}_{\mathrm{A}}=\mathrm{chl}_{\mathrm{I}}-\mathrm{chl}_{\mathrm{O}}
$$

and geometrically:

$$
\operatorname{Def}_{G}=10^{\log _{\text {chl }} E-\text { chlo }_{O}}
$$

The arithmetic deficit, $\operatorname{Def}_{A}$, indicates the absolute difference between expected chl $\left(\mathrm{chl}_{E}\right)$ and observed chl $\left(\mathrm{chl}_{O}\right)$, while the geometric deficit, Def ${ }_{\mathrm{G}}$, indicates the relative difference in terms of factors. We combined the effects of the loss rates and turbidity as follows:

$$
\text { Total losses }=k_{\text {TOT }} \cdot\left(Z_{E} \cdot Z_{M}{ }^{-1}\right)
$$




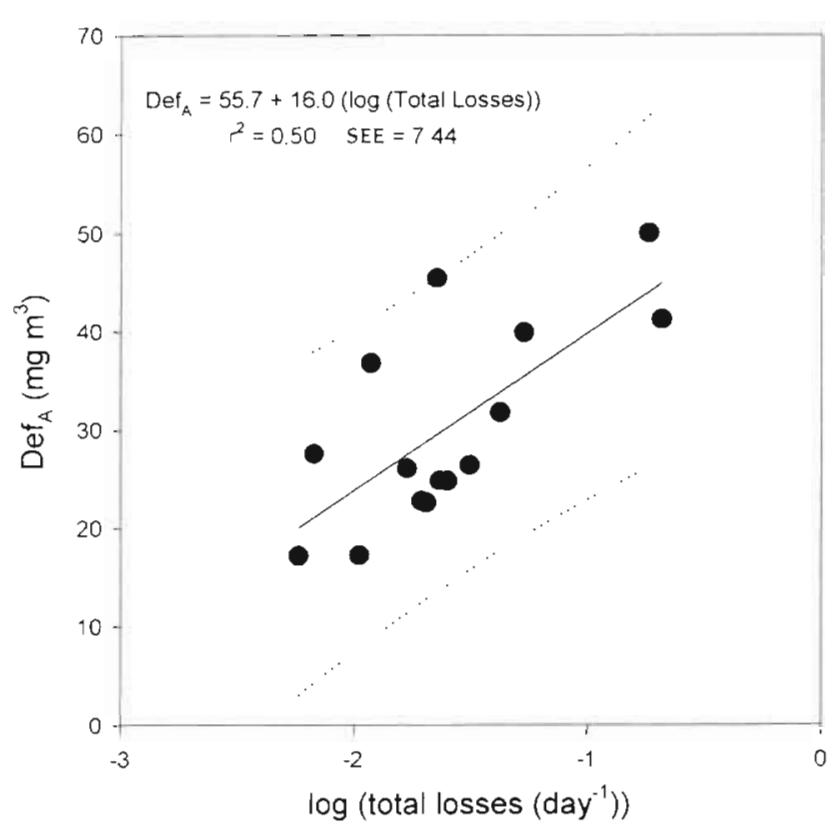

Fig. 7 Empirical model predicting the arithmetic chl deficit $\left(\right.$ Def $\left._{A}\right)$ as a function of log total losses; dashed lines are $95 \%$ prediction intervals

where $k_{\text {TOT }}$ is the sum of $k_{\mathrm{f}}, k_{\mathrm{s}}$ and $k_{\mathrm{h}}$ and $Z_{\mathrm{E}} \cdot Z_{\mathrm{M}}{ }^{-1}$ is the ratio of the euphotic depth to the mean depth as in Eq. (8). In other words, if the euphotic depth is half of the mean depth of the estuary, the losses are effectively doubled. We estimated a linear model predicting these deficits as a function of the total loss and were able to fit the model:

$$
\operatorname{Def}_{\mathrm{A}}=55.7+16.0 \cdot \log (\text { Total losses })
$$

This model accounted for $50 \%$ of the variation in Def $_{A}$ (Fig. $7 ; n=15, p<0.003$ ). We also fit other linear and nonlinear models, using Secchi depth and other combinations of $k_{\text {TOT }}$ and turbidity. None of these models had stable residuals.

\section{DISCUSSION}

The strong relations between chl and total nutrients (Fig. 2) support our initial hypotheses that estuarine phytoplankton biomass is tightly correlated with bottom-up nutrient factors and that the relations can be captured using a comparative empirical approach. The applicability of the comparative approach to estuarine systems is encouraging as this approach has provided simple ecological models that have contributed to effective lake management (e.g. OECD 1982). In contrast, there have been few ecological models available to support coastal management efforts and those that exist are frequently estuary-specific, information- intensive and expensive (cf. Linker et al. 1993, Bricker \& Stevenson 1996).

These results also demonstrate that this empirical approach can successfully identify simple patterns across estuaries. Such cross-system relations require that each system, whether a lake or an estuary, can be represented by 'characteristic' values. This requirement has meant that researchers implicitly assume that the systems are at steady state and are relatively homogenous in order to minimize sampling effort. Estuaries have complex hydraulic regimes, are considered spatially heterogeneous and generally have shorter water residence times than lakes due to their relatively open exposure to the sea (Bowden 1980). These characteristics could constrain the use of empirical approaches. However, with a slightly more intense sampling regime than that typically used in lakes, representative values for estuaries can be estimated ( $T$. Nayar \& J. J. Meeuwig unpubl.).

The strength of the relations also appears insensitive to residence time, which ranged between 3 and $356 \mathrm{~d}$. Provided the residence time exceeds the specific growth rate of phytoplankton, patterns between chl and nutrients are possible. This result is consistent with those of Basu \& Pick (1996), who demonstrated a strong relation between chl and TP $\left(\mathrm{r}^{2}=0.76\right)$ in rivers with residence times ranging between 3 and $19 \mathrm{~d}$.

That the relation between chl and TN is marginally stronger than that between chl and TP (Fig. 2) suggests that $T N$, rather than $T P$, limits estuarine chl, and thus our third hypothesis should be rejected. This interpretation reflects the assumption that the relative strength of patterns indicates the relative importance of their respective independent variables to the dependent variable (Smith 1979). The average TN:TP ratio of 4.5 also supports the argument for $\mathrm{TN}$ as the key limiting nutrient in these estuaries.

Despite the general applicability of a limnological approach to estuaries, the relations between chl and nutrients differ in lakes and estuaries. While the slopes of the chl:TP and chl:TN relations are similar in lakes and estuaries, the intercepts of the estuarine nutrient models are approximately 1, to 2 orders of magnitude lower than those of lake nutrient models. Thus, the yield of chl per unit TP or TN is much lower in these estuaries. This result was unexpected as a chl:TP relation developed for estuaries in North and South Carolina (US EPA unpubl. data) is indistinguishable from lake relations (Fig. 8), suggesting that estuarine phytoplankton can respond to nutrients similarly to lake phytoplankton.

Other researchers have also noted a lower phytoplankton yield in coastal waters (cf. Contreras \& Kerekes 1993, Boynton et al. 1996) on the order of a 2 to 8 -fold discrepancy. A discrepancy on the level of 2 


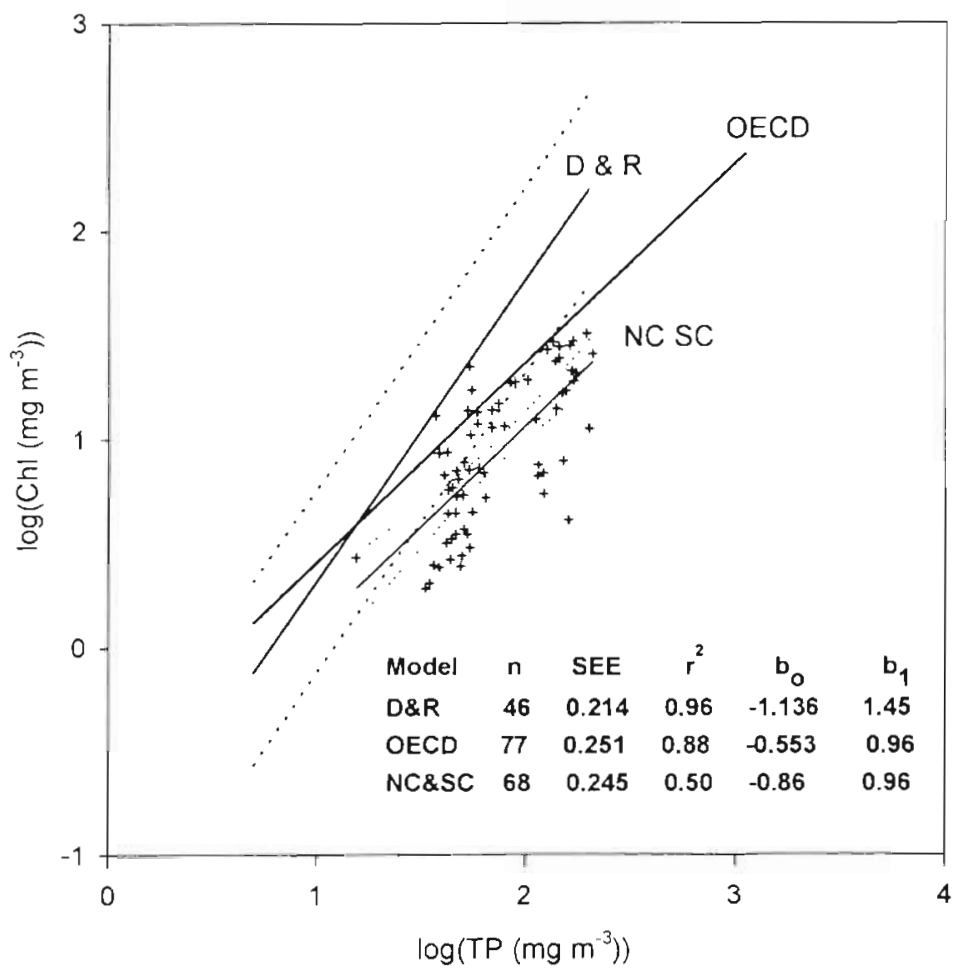

Fig. 8. Chl:TP relations from Dillon \& Rigler (1974) (D\&R), OECD (1982) and North and South Carolina estuaries (NC\&SC) (US EPA unpubl. data)

orders of magnitude was unexpected as phytoplankton element requirements are fairly similar in lakes and estuaries (Hecky \& Kilham 1988). The result cannot be attributed to estuarine flushing as this would result in a general dilution with low concentrations of both phytoplankton biomass and nutrients rather than a low yield. Herbivory as a top-down control of phytoplankton biomass or light limitation as a function of turbidity are the 2 most likely explanations.

Since Carpenter et al. (1985) defined their trophic cascade model, interest in top-down control of phytoplankton biomass has increased. Mazumder (1994) demonstrated that the chl:TP relation is weaker in lakes where large filtering Daphnia are present than in lakes lacking Daphnia, and that the yield of chl per unit TP is lower in lakes with Daphnia by approximately a factor of 3. Quiros (1990) also demonstrated that herbivory by macrozooplankton in Argentinean lakes and reservoirs strongly decreased the intercept of his chl:TP relation by almost an order of magnitude $(-1.9$ to -2.6$)$. Mellina et al. (1995) showed similar results for zebra mussels Dreissena polymorpha in Lake Erie, Lake St. Clair and experimental aquaria. Our mass-balance calculation of the impact of mussel farms on the standing stock of algae suggests that phytoplankton biomass in the 6 estuaries with mussel farms has been reduced by 45 to
$88 \%$ (Table 5). This level is similar to that found in an enclosure study in which Mytilus edulis reduced phytoplankton biomass by 54 to $90 \%$ of controls (Riemann et al. 1988). It is likely that suspension feeders are also exerting pressure on the phytoplankton biomass in the other 9 estuaries as all support natural clam and oyster Crassostrea virginica populations. For instance, the Dunk and Wilmot estuaries, in particular, provide 60 to $70 \%$ of the $1.6 \times 10^{6} \mathrm{~kg}$ annual oyster harvest. Estimating total biomass from Sephton \& Bryan (1989), and using a filtration rate of $0.002 \mathrm{~m}^{3} \mathrm{~d}^{-1} \mathrm{~g}^{-1}$ dry wt (Bacher et al. 1995), an additional 29\% of the phytoplankton deficit in Dunk can be explained.

The turbidity analysis suggests that a small euphotic zone can sufficiently decrease PP to account for 6 to $79 \%$ of the phytoplankton deficit (Table 6). Light limitation as a function of turbidity appears feasible, particularly in the deeper estuaries such as Grand and Mill River. These estuaries show no evidence of stratifying with respect to salinity and temperature; thus, it is likely that the phytoplankton spend time below the euphotic zone.

Generally, herbivory and turbidity account for the deficit between observed phytoplankton biomass and that expected from lake models, with an average deficit of $32 \%$ remaining. This is as accurate as we can expect because PP itself has a coefficient of variation of approximately $30 \%$ and we cannot estimate $B$ with greater accuracy than PP. In comparison, the empirical model left $50 \%$ of the deficit unexplained. These 2 approaches to explaining the deficit complement each other: the mass-balance model allows a more refined breakdown of the loss rates but requires an estimate of $\mathrm{PP}$; the empirical model is a black box in terms of loss rates but does not require an estimate of PP. Because both approaches demonstrate the importance of herbivory and turbidity, together they make a strong case for the deficit as a function of these 2 factors.

The effectiveness of the mass-balance model suggests that once herbivory and turbidity are included in the analysis, lakes and estuaries show similar patterns between phytoplankton biomass and nutrients. Although the approach is particularly effective in the estuaries where herbivory is a dominant factor, it is less effective in the estuaries in which no mussel aquaculture occurs, decreasing the deficit by only $54 \%$ on average. It is particularly ineffective in very small estuaries (e.g. North Lake) and in the very shallow, turbid estuaries (e.g. Dunk, Percival, Wilmot). In these shallow, turbid estuaries, a decrease in PP due to light lim- 
itation seems less feasible than in the deeper estuaries because these shallow estuaries support a large biomass of the benthic alga Ulva lactuca despite the very high turbidity. If light were limiting, it is unlikely that U. lactuca would be thriving to this extent.

Thus, although we have argued that turbidity indicates light limitation, it may be a surrogate for another variable controlling phytoplankton biomass. We speculate that this variable is iron. Iron is most usually thought of as a limiting nutrient in certain areas of the ocean (Martin \& Fitzwater 1988). However, in areas of excess iron, iron scavenging of phosphorus may make phosphorus unavailable to phytoplankton and thus limit phytoplankton biomass (Froelich 1988). Natural clays with iron hydroxides adsorb phosphorus under acid conditions such as those found in the iron-rich soils of. PEI (MacDougall et al. 1988). Soil particles with $P$ adsorbed to them would then be transported into the estuaries where this $P$ may remain relatively unavailable to the phytoplankton. Thus, TP values which do not discriminate between available and unavailable $P$ may result in a low yield in systems where an unusually high proportion of $\mathrm{P}$ is unavailable to the algae. As the correlation between particulate TP and particulate iron is strong ( $r=0.95$; Eyre 1994), the proportion of unavailable P should be constant and a function of iron and thus of turbidity.

Control of $\mathrm{P}$ availability by iron was considered by Schindler (1981), who suggested that P limitation in lakes might in fact be a function of high iron concentrations recycled from the sediments as a result of the reducing conditions of the hypolimnion. In coastal systems, Krom et al. (1991) also invoked adsorption of P by iron resulting in $\mathrm{P}$ limitation of the eastern Mediterranean, which receives high levels of iron-laden dust from the Sahara.

Iron control of P may thus partly account for the low chl yields in turbid estuaries where the mass-balance analysis accounted for only a small proportion of the phytoplankton deficit. Iron control of $\mathrm{P}$ may also account for the tight correlation between chl and nutrients. In the absence of nutrient limitation, the pattern between chl and nutrients should only occur if the variable that limits phytoplankton biomass covaries with nutrients. It is likely that iron covaries with nutrients in the PEI estuaries: iron is correlated with turbidity as it enters the estuaries on soil particles and turbidity is correlated with nutrients (Secchidepth:TN, $r=-0.68$; Secchi depth $\cdot T P, r=-0.57$ ). If iron controls the amount of $\mathrm{P}$ available to phytoplankton, an excess of iron would result in a reduced phytoplankton yield and lead to effective P limitation irrespective of the TN:TP ratio.

Indirect P limitation via excess iron would contradict the earlier conclusion that these estuaries are $\mathrm{N}$ lim- ited. However, the evidence for $\mathrm{N}$ limitation is not that compelling. First, the coefficient of determination for the chl:TN relation $\left(r^{2}=0.72\right)$ is only marginally greater than that for the chl:TP $\left(\mathrm{r}^{2}=0.65\right)$ and it is unclear whether such a small difference is sufficient to indicate the relative importance of $\mathrm{N}$ and $\mathrm{P}$ in limiting chl. Moreover, because TN and TP covary $(r=0.82)$, chl will be strongly correlated with both nutrients. Second, the low TN:TP ratios (3.1 to 8.7) that suggest $N$ limitation may be a function of the loading ratio of $N$ and $P$ to the estuary rather than a function of phytoplankton uptake. Given the relatively short residence times of the estuaries, it is unlikely that ambient nutrient ratios are determined by phytoplankton uptake (Smith 1984). Such indirect control of phytoplankton biomass has been suggested by other researchers as welli Smith \& Hollibaugh (1.989) argue that carbon control of net heterotrophic systems is masked by an apparent $\mathrm{N}$ limitation.

In conclusion, strong patterns can be identified between chl and total nutrients in estuaries. However, the relative strength of these patterns and the TN:TP ratio cannot be used to infer which nutrient is limiting phytoplankton biomass. Thus, although such models are useful tools for coastal managers to predict phytoplankton biomass from nutrient concentrations, they cannot be used to support decisions with respect to single nutrient reduction strategies. The low yield of chl per unit nutrient points to the importance of other factors such as herbivory and turbidity, and potentially to indirect control by iron, in determining phytoplankton biomass. The comparison of these estuaries to lakes, and the use of mass-balance and empirical models to account for the deficit, suggests that, once the effects of herbivory and turbidity are accounted for, phytoplankton response to nutrients is similar in lakes and estuaries.

Acknowledgements. We thank M. Trudel for his generous advice on mass-balance models and an anonymous reviewer for suggesting the empirical model. Field and laboratory assistance was provided by $E$. Sunderland, D. Chamberland and T. Nayar. In PEI, B. Penak (Bedeque Bay Environmental Management Association), R. Angus (Dept of Fisheries and Oceans), and B. Raymond (PEI Dept of Fisheries and Environment) provided essential logistic support. This work was supported by the National Science and Engineering Research Council of Canada and is a contribution from the McGill University Limnology Research Group.

\section{LITERATURE CITED}

Alpkem (1992) User's manual. Alpkem, Wilsonville, OR Bacher C, Bioteau H, Chapelle A (1995) Modelling the impact of cultivated oyster populations on the nitrogen dynamics: the Thau Lagoon Case (France). Ophelia 42:29-54

Basu B, Pick F (1996) Factors regulating phytoplankton and zooplankton biomass in temperate rivers. Limnol Oceanogr $41(7): 1572-1577$ 
Bergmann M. Peters RH (1980) A simple reflectance method for the measurement of particulate pigment in lake water and its application to phosphorus-chlorophyll-seston relations. Can J Fish Aquat Sci 37:111-114

Bowden KF (1980) Physical factors: salinity, temperature, circulation and mixing processes. In: Olausson E, Cato I (eds) Chemistry and biogeochemistry of estuaries. John Wiley and Sons, Chichester, $p 37-70$

Boynton WR, Kemp WM, Keefe CW (1982) A comparative analysis of nutrients and other factors influencing estuarine productivity. In: Kennedy VS (ed) Estuarine comparisons. Academic Press, New York, p 60-90

Boynton WR, Murray L, Hagy JD, Stokes C, Kemp WM (1996) A comparative analysis of eutrophication patterns in a temperate coastal lagoon. Estuaries 19:408-421

Bricker SB, Stevenson JC (1996) Nutrients in coastal waters: d chronology and symopsis of research. Estuaries 19(2b): $337-341$

Bricker SB, Clement CG. Frew S, Harmon MR, Pirhalla DE (1995) NOAA's Estuarine Eutrophication Survey, Vol 1: Mid-Atlantic region. Office of Ocean Resources Conservation and Assessment, National Ocean Service, National Oceanic and Atmospheric Administration, Silver Spring, MD

Canadian Hydrographic Service (1980) Bathymetric charts (nos. 4420, 4421, 4422, 4425, 4459, 4467, 4491, 4492). Ministry of Supply and Services, Ottawa

Carpenter SR, Kitchell JF, Hodgson JR (1985) Cascading trophic interactions and lake productivity. BioSci 35: $634-639$

Cole GA (1994) Textbook of limnology, 4th edn. Waveland Press, Prospect Heights, IL

Contreras F, Kerekes J (1993) Total phosphorus - chlorophyll relationships in tropical coastal lagoons in Mexico. Verh Int Verein Theor Angew Limnol 25:448-451

Cooper SR (1995) Chesapeake Bay watershed historical land use impact on water quality and diatom communities. Ecol Appl 5(3):703-723

Department of Fisheries and Oceans (1996) Canadian tide and current tables 1996, Vol 2. Gulf of St. Lawrence. Fisheries and Oceans Communications Directorate, Ottawa

Dillon PJ, Rigler FH (1974) The phosphorus - chlorophyll relationship in lakes. Limnol. Oceanogr 19:767-773

Edmondson WT (1991) The uses of ecology: Lake Washington and beyond. Univ of Washington Press, Seattle

Environment Canada (1990) Activities affecting surface water resources: a general overview. The Canada-PEJ. Water Management Agreement. Ministry of Supply and Services, Ottawa

Eyre B (1994) Nutrient biogeochemistry in the tropical Moresby River estuary system, North Queensland, Australia. Estuar Coast Shelf Sci 39:15-31

Fairbridge RW (1980) The estuary: its definition and geodynamic cycle. In: Olausson E, Cato I (eds) Chemistry and brogeochemisry of estuarıes. John Wiley and Sons, Chichester, p 1-35

Famme P, Riisgård HU, Jorgensen CB (1986) On direct measurement of pumping rates in the mussel Mytilus edulis. Mar Biol 92:323-327

Froelich PN (1988) Kinetic control of dissolved phosphate in natural rivers and estuaries: a primer on the phosphate buffer mechanism. Limnol Oceanogr 33:649-668

Hecky RE, Kilham P (1988) Nutrient limitation of phytoplankton in freshwater and marine environments: a review of recent evidence on the effects of enrichment. Limnol Oceanogr 33:796-822

Himelmann D, Stewart NE (1979) Soil erosion studies in PEl.
Paper Soil erosion workshop. April 17-19. Nova Scotia Agricultural College, Truro

James HR, Birge EA (1938) A laboratory study of the adsorption of light by lake waters. Trans Wis Acad Sci Arts Lett $31: 1-154$

Jergensen CB (1966) Biology of suspension feeders. Pergamon Press, Oxford

Krom MD, Kress N, Brenner S, Gordon Ll (1991) Phosphorus limitation of primary productivity in the eastern Mediterranean Sea. Limnol Oceanogr 36:424-432

Linker LC, Stigall GE, Chang CH, Donigian AS (1993) The Chesapeake Bay watershed model. CSC MD1.3-9

MacDougall Jl, Veer C, Wilson F (1988) Soils of Prince Edward Island: Prince Edward Island Soil Survey No. 8354. Ministry of Supply and Services, Ottawa

Martin JH, Fitzwater SE (1988) Iron deficiency limits phytoplankton growth in the north-east Pacific subarctic. Nature 331:341-343

Mazumder A (1994) Patterns of algal biomass in dominant odd- vs even-link lake ecosystems. Ecology 75(4) $1141-1149$

Mellina E, Rasmussen JB, Mills EL (1995) Impact of zebra mussels (Dreissena polymorpha) on phosphorus cycling and chlorophyll in lakes. Can J Fish Aquat Sci 52 $2553-2579$

Menzel DW, Corwin N (1965) The measurement of total phosphorus in seawater based on the liberation of organically bound fractions by persulfate oxidation. Limnol Oceanogr $10: 280-282$

Mohlenberg F, Riisgård HU (1979) Filtration rates using a new indirect technique for 13 species of suspension feeding bivalves. Mar Biol 54:143-147

Monbet Y (1992) Controls of phytoplankton biomass in estuaries - a comparative analysis of microtidal and macrotidal estuaries. Estuaries 15:563-571

Nixon SW (1981) Remineralization and nutrient cycling in coastal marine ecosystems. In: Neilson BJ, Cronin LE (eds) Estuaries and nutrients. Humana Press, Clifton, NJ, p $111-138$

Nixon SW (ed) (1990) Marine eutrophication: a growing international prablem. Ambio 19

Nixon SW (1995) Coastal marine eutrophication: a definition, social causes and future concerns. Ophelia 41:199-219

Nixon SW, Ovıatt CA, Frithsen J, Sullıvan B (1986) Nutrients and the productivity of estuarine and coastal marine ecosystems. J Limnol Soc South Afr 12(1/2):43-71

O'Connor DJ (1981) Modelling of eutrophication in estuaries. In: Neilson BJ, Cronin LE (eds) Estuaries and nutrients. Humana Press, Clifton, NJ, p 183-224

OECD (1982) Eutrophication of waters: monitoring assessment and control. Organisation for Economic Cooperation and Development, Paris

Oviatt C, Doering P, Nowicki B, Reed L, Cole J, Frithsen J (1995) An ecosystem level experiment on nutrient limitation in temperate coastal marine environments. Mar Ecol Prog Ser 116:171-179

Oviatt C, Keller AA, Sampar PA, Beatty LL (1986) Patterns of productivity during eutrophication: a mesocosm experiment. Mar Ecol Prog Ser 28:69-80

Paerl H (1995) Coastal eutrophication in relation to atmospheric nitrogen deposition: current perspectives. Ophelia 41:237-259

Prairie YT, Duarte CM, Kalff J (1989) Unifying nutrientchlorophyll relationships in lakes. Can J Fish Aquat Sci 46 : $1176-1182$

Quiros R (1990) Factors related to variance of residuals in chlorophyll-total phosphorus regression in lakes 
and reservoirs of Argentina. Hydrobiologia 200/201: $343-355$

Redfield AC (1958) The biological control of chemical factors in the environment. Am Sci 46:205-222

Ryther JH, Dunstan WM (1971) Nitrogen phosphorus and eutrophication in the coastal marine environment. Science 1.71:1008-1013

Riemann B, NieIsen TG, Horsted SJ, Biørnsen PK, Pock-Steen $J$ (1988) Regulation of phytoplankton biomass in estuarine enclosures. Mar Ecol Prog Ser 48:205-215

Rosenberg R, Elmgren R, Fleischer S, Jonsson P, Persson G, Dahlin H (1990) Marine eutrophication case studies in Sweden. Ambio 19:102-1.08

Sakamoto M (1966) Primary production by phytoplankton community in some Japanese lakes and its dependence on lake depth. Arch Hydrobiol 62:1-28

SAS Institute Inc (1985) SAS/STAT user's guide, release 6.03 . SAS Institute Inc, Cary, NC

Schindler DW (1977) Evolution of phosphorus limitation in lakes. Science 195:260-262

Schindler DW (1981) Studies of eutrophication in lakes and their relevance to the estuarine environment. In: Neilson BJ, Cronin LE (eds) Estuaries and nutrients. Humana Press, Clifton, NJ, p 71-82

Sephton TW, Bryan CF (1989) Changes in the abundance and distribution of the American oyster population of the Dunk River Public Fishing Area of Bedeque Bay, Prince Edward Island. Can Tech Rep Fish Aquat Sci 1677:v1+21 pp

Smith SV (1984) Phosphorus versus nitrogen limitation in the marine environment. Limnol Oceanogr 29:1149-1160

Editorial responsibility: Otto Kinne (Editor),

Oldendorf/Luhe, Germany
Smith SV, Hollibaugh JT (1989) Carbon-controlled nitrogen cycling in a marine 'macrocosm': an ecosystem-scale model for managing cultural eutrophication. Mar Ecol Prog Ser 52:103-109

Smith VH (1979) Nutrient dependence of primary productivity in lakes. Limnol Oceanogr 24:1051-1064

Solórzano L, Sharp JH (1980) Determination of total dissolved nitrogen in natural waters. Limnol Oceanogr 25:751-754

Tamminen T (1995) Nitrate and ammonium depletion rates and preferences during a Baltuc sping bloom. Mar Ecol Prog Ser 120:123-133

Turner RE, Rabalais NN (1994) Coastal eutrophication near the Mississippi river delta. Nature 368:619-621

Vahl $O$ (1973) Pumping and oxygen consumption rates of $M$. edulis L. of different sizes. Ophelia 12:45-52

Vollenweider RA, Marchetti R, Viviani R (eds) (1992) Marine coastal eutrophication. Sci Tot Env Supplement

Walne PR (1972) The influence of current speed, body size and water temperature on the filtration rate of 5 species of bivalves. J Mar Biol Assoc UK 52:345-374

Wetzel RG (1982) Limnology, 2nd edn. Saunders College Publishing, Philadelphia

Widdows J, Fieth P, Worrall CM (1979) Relationships between seston, available food and feeding activity in the common mussel Mytilus edulis. Mar Biol 50:195-207

Winter JE (1973) The filtration rate of Mytilus edulis and its dependence on algal concentration measured by a continuous automatic recording approach. Mar Biol 22:317-328

Zar JH (1984) Biostatistical analysis. Prentice-Hall, Englewood Cliffs, NJ

Submitted: July 29, 1997; Accepted: June 2, 1998

Proofs received from author(s): September 3,1998 